\title{
SIFAT FOTOKATALITIK SERBUK ZnO TERDOPING ALUMINIUM DALAM MENDEGRADASI LARUTAN METIL BIRU
}

\author{
ANNISA APRILIA*, DAVI PUTRI HANAVI, LUSI SAFRIANI, AYI BAHTIAR, SRI \\ SURYANINGSIH, RESTI RAHAYU DWI AGUSTINI \\ Departemen Fisika Fakultas MIPA Universitas Padjadjaran, \\ Jl. Raya Bandung-Sumedang Km 21, Jatinangor 45363 \\ *email : a.aprilia@phys.unpad.ac.id
}

\begin{abstract}
Abstrak. Pengujian sifat fotokatalitik serbuk nano $\mathrm{ZnO}$ terdoping Aluminium dalam mendegradasi larutan metil biru (MB) telah berhasil dilakukan. Sifat fotokatalitik serbuk $\mathrm{ZnO}$ terdoping $\mathrm{Al}$ dikaitkan dengan karakteristik fotoluminesensi, morfologi serbuk dan struktur kristal. Serbuk ZnO tanpa doping turut diuji struktur-morfologinya beserta sifat fotokatalitik sebagai pembanding. Senyawa dopan yang digunakan adalah $\mathrm{Al}\left(\mathrm{NO}_{3}\right)_{3}$ dengan konsentrasi $0,5 \%$ massa terhadap senyawa prekursor $\mathrm{Zn}\left(\mathrm{CH}_{3} \mathrm{COOH}\right)_{2} \cdot 2 \mathrm{H}_{2} \mathrm{O}$. Diketahui bahwa penambahan dopan Al dapat mereduksi ukuran partikel dan ukuran kristal yang memiliki orientasi bidang (002). Selain itu, berdasarkan hasil pencitraan SEM (scanning electron microscope), terdapat perbedaan morfologi serbuk akibat penambahan aluminium. Pada serbuk $\mathrm{ZnO}$ terdoping $\mathrm{Al}$, terbentuk morfologi berupa kepingan yang kemungkinan merupakan penumpukan serbuk berukuran nano. Berdasarkan pengujian karakteristik fotoluminesensi diketahui bahwa terjadi penurunan intensitas emisi (fotoluminesensi) pada sampel $\mathrm{ZnO}$ terdoping Al. Penurunan intensitas fotoluminesensi tersebut dapat dikaitkan dengan berkurangnya peristiwa rekombinasi pasangan elekton dan hole. Pasangan elektron dan hole yang akhirnya menjadi pembawa muatan bebas kemudian akan bereaksi dengan $\mathrm{OH}$ dan juga oksigen yang akhirnya membentuk hidroksil radikal. Hidroksil radikal inilah yang selanjutnya akan memutus rantai ikatan metil biru di dalam air. Hal ini menjelaskan sifat fotokatalitik pada sampel $\mathrm{ZnO}$ terdoping $\mathrm{Al}$ 0,5\% massa yang ternyata memiliki laju kinetik degradasi yang lebih besar dibandingkan dengan $\mathrm{ZnO}$.
\end{abstract}

Kata kunci: metil biru, metal oksida, $\mathrm{Al}$ doped $\mathrm{ZnO}$, fotokatalis, fotoluminesensi

\begin{abstract}
The photocatalytic properties of $\mathrm{Al}$ doped $\mathrm{ZnO}$ ( $\mathrm{ZnO}: \mathrm{Al})$ nano powder in degradation of methylene blue as contaminant (MB) has been successfully carried out. $\mathrm{Al}$ doped $\mathrm{ZnO}$ photocatalytic characteristic was correlated with photoluminescence characteristics, powder morphology and crystal structure. Undoped $\mathrm{ZnO}$ nano powder was also prepared and characterized also as comparison. Aluminum nitrate $\left(\mathrm{Al}\left(\mathrm{NO}_{3}\right)_{3}\right)$ was used as dopant material with a concentration of $0.5 \mathrm{wt} \%$ to the $\mathrm{Zn}\left(\mathrm{CH}_{3} \mathrm{COOH}\right)$ ${ }_{2} .2 \mathrm{H}_{2} \mathrm{O}$ as precursor. It is known that the addition of dopant $\mathrm{Al}$ can reduce particle and crystal size specifically in (002) plane orientation. In addition, based on SEM (scanning electron microscope) imaging results, $\mathrm{Al}$ doped $\mathrm{ZnO}$ powder has a unique morphological likely flower sheet. This unique morphology might be formed by nano-sized fine powder. Based on photoluminescence spectra, the photoluminescence quenching is observed for $\mathrm{Al}$ doped $\mathrm{ZnO}$ samples. The decrease in photoluminescence intensity can be attributed to the reduction of recombination process of electron-hole pairs. The pair of electrons and holes that eventually become free charge carriers was reacted with $\mathrm{OH}$ and oxygen produce hydroxyl radicals. Thus the methylene blue will be degraded caused by the existence of hydroxyl radical. This is also explaining that the photocatalytic behavior of $\mathrm{Al}$ doped $\mathrm{ZnO} 0.5 \mathrm{wt} \%$ show a high kinetic degradation rate compared to $\mathrm{ZnO}$ undoped.
\end{abstract}

Keywords: methylene blue, $\mathrm{Al}$ doped $\mathrm{ZnO}$, photocatalyst, photoluminescence

JIIF (Jurnal Ilmu dan Inovasi Fisika), ISSN: 2549-0516 


\section{Pendahuluan}

Aplikasi nanoteknologi pada material fotokatalis menghasilkan peningkatan efisiensi pengolahan limbah, dan termasuk salah satu metoda yang unggul dalam menghilangkan kontaminasi/polutan di dalam air. Penggunaan material fotokatalis dapat mempercepat proses penghancuran polutan tertentu atau melumpuhkan senyawa beracun dan patogen [1]. Saat ini, beberapa jenis metal oksida (struktur nano) telah diuji dalam pemeliharaan air tanah, air permukaan dan air minum yang terkontaminasi oleh logam beracun, organik dan zat terlarut anorganik dan mikroorganisme [2]. Bersamaan dengan radiasi elektromagnetik dari sinar matahari, penggunaan nanopartikel metal oksida memperlihatkan aktivitas fotokatalitik yang tinggi dalam proses penjernihan air [1]. Contoh nanomaterial metal oksida yang umum digunakan sebagai material aktif fotokatalis diantaranya adalah Titanium oxide $\left(\mathrm{TiO}_{2}\right)$, Zinc Oxide $(\mathrm{ZnO})$, Magnesium Oxide $(\mathrm{MgO})$, Manganese Oxide $\left(\mathrm{MnO}_{2}\right)$ dan Ferric Oxide $\left(\mathrm{Fe}_{3} \mathrm{O}_{4} / \mathrm{Fe}_{2} \mathrm{O}_{3}\right)$ [3].

Diantara beberapa jenis metal oksida yang berpotensi sebagai fotokatalis pada pengolahan air, $\mathrm{ZnO}$ memiliki kelebihan berupa reaktivitas permukaan yang tinggi dan memiliki efisiensi fotokatalis yang besar, khususnya bila dibandingkan dengan $\mathrm{TiO}_{2}$. Selain itu jika dibandingkan dengan $\mathrm{TiO}_{2}, \mathrm{ZnO}$ relatif mudah terdispersi dalam air dan berakhir sebagai $\mathrm{Zn}$ di ekosistem sehingga tidak berpotensi mengkontaminasi lingkungan [1]. ZnO memiliki nilai Energy Gap ( $\left.\mathrm{E}_{\mathrm{g}}\right)$ berkisar antara 3,2-3,37 eV sehingga mampu bekerja sebagai fotokatalis pada rentang sinar ultra violet (UV) $(\lambda<387 \mathrm{~nm})$ [4]. Sifat fotokatalitik dari $\mathrm{ZnO}$ erat kaitannya dengan sifat listrik dan sifat optik, dimana keduanya dipengaruhi pula oleh struktur dan morfologi kristal. Atas dasar hal tersebut, sifat fotokatalitik pada dasarnya dapat ditingkatkan, salah satunya dengan pemberian dopan logam/nonlogam.

Logam aluminium merupakan unsur yang sering digunakan sebagai doping pada $\mathrm{ZnO}$, hal ini didasarkan pada peningkatan nilai mobilitas elektron dan peningkatan transparansi lapisan tipis $\mathrm{ZnO}$ dalam rentang cahaya tampak. Selain itu, pemberian doping Al juga diketahui dapat mereduksi ukuran partikel $\mathrm{ZnO}$ sehingga dapat meningkatkan aktifitas luas permukaan menjadi lebih besar. Berdasarkan penelitian kami sebelumnya, penambahan dopan $\mathrm{Al}$ pada $\mathrm{ZnO}$ paling efektif dalam meningkatkan sifat listrik dan optik, khususnya untuk diaplikasikan sel surya [5]. Oleh karena itu, pada penelitian ini dikaji karakteristik fotokatalis partikel $\mathrm{ZnO}$ yang didoping oleh atom $\mathrm{Al}$ melalui senyawa $\mathrm{Al}\left(\mathrm{NO}_{3}\right)_{3}$ sebanyak 0,5 \% massa terhadap senyawa prekursor $\mathrm{Zn}\left(\mathrm{CH}_{3} \mathrm{COOH}\right)_{2} \cdot 2 \mathrm{H}_{2} \mathrm{O}$. Karakteristik fotokatalis tersebut kemudian dikaitkan dengan struktur-morfologi dan karakteristik fotoluminesensi dari serbuk $\mathrm{ZnO}$ terdoping $\mathrm{Al}$ yang dihasilkan.

\section{Metode Penelitian}

Penelitian ini dibagi menjadi tiga tahap yaitu proses sintesis $\mathrm{ZnO}$ tak terdoping dan terdoping $\mathrm{Al}$ ( $\mathrm{ZnO}: \mathrm{Al})$, struktur-morfologi dan fotoluminesensi, beserta pengujian fotokatalis, dan penggunaan berulang $\mathrm{ZnO}: \mathrm{Al}$ dan $\mathrm{ZnO}$ sebagai fotokatalis. Untuk proses sintesis, jenis prekursor yang digunakan adalah Zinc Acetate Dihydrate $\left(\mathrm{Zn}\left(\mathrm{CH}_{3} \mathrm{COOH}\right)_{2} \cdot 2 \mathrm{H}_{2} \mathrm{O}\right)$, methanol sebagai pelarut, $\mathrm{NaOH}$ sebagai ligand dan alumunium nitrat $\left(\mathrm{Al}\left(\mathrm{NO}_{3}\right)\right.$ sebagai senyawa dopan. Serbuk metil biru $(\mathrm{MB})$ yang dilarutkan di dalam aquades digunakan sebagai model larutan limbah, yang selanjutnya digunakan dalam pengujian sifat fotokatalitik. 
Setelah serbuk $\mathrm{ZnO}$ selesai disintesis, beberapa jenis karakterisasi yang dilakukan meliputi pengujian struktur kristal menggunakan perangkat difraksi sinar-X, pengamatan morfologi menggunakan pencitraan SEM (scanning electron microscopy), karakterisasi sifat optik menggunakan spektrometer fotoluminesensi, serta pengujian sifat fotokatalis $\mathrm{ZnO}$ dan $\mathrm{ZnO}$ :Al. Untuk mengetahui stabilitas penggunaan material katalis, dilakukan pengujian berulang pada sampel $\mathrm{ZnO}: \mathrm{Al}$. Untuk mengetahui kuantitas degradasi kandungan metil biru di dalam air dilakukan pengamatan spektrum UV-Vis dan pengujian spektrum serapan gugus fungsi menggunakan spektrometer Fourier Transform Infrared Spectroscopy (FTIR). Pada pengujian sifat fotokatalis, yaitu dengan mencampurkan serbuk $\mathrm{ZnO}$ pada larutan metilen biru, yang kemudian dilakukan proses penyinaran menggunakan lampu UV. Proses pengamatan dilakukan dengan mengukur laju degradasi kandungan metil biru berdasarkan spektrum absorbansi yang dihasilkan dalam interval waktu tertentu.

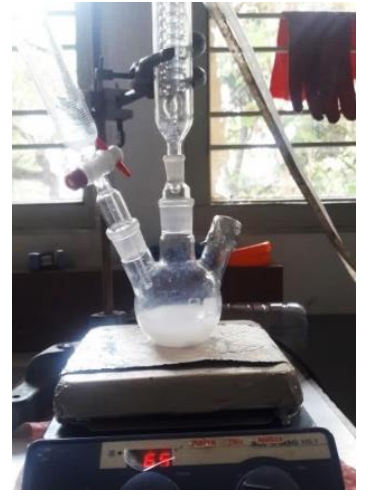

(a)

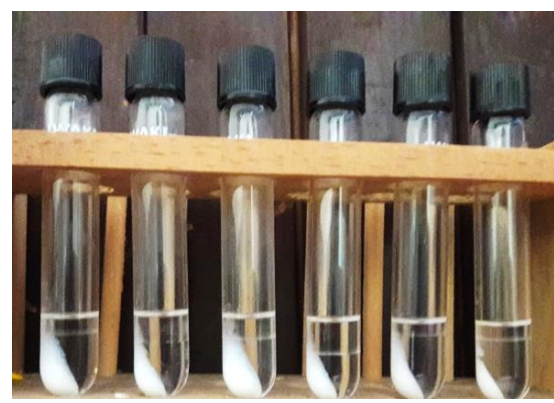

(b)

Gambar 1. (a) Proses sintesis sol-gel. (b) Endapan gel hasil sintesis

Proses sintesis serbuk $\mathrm{ZnO}$ dan $\mathrm{ZnO}: \mathrm{Al}$ dilakukan dengan menggunakan metode sol-gel. Senyawa precursor Zinc Acetate Dihydrate dengan konsentrasi 4,5 mmol dilarutkan dengan $42 \mathrm{ml}$ metanol kemudian diaduk menggunakan magnetic stirrer selama 10 menit pada suhu $65^{\circ} \mathrm{C}$. Selanjutnya, 0,28 gr $\mathrm{NaOH}$ dan $\mathrm{Al}\left(\mathrm{NO}_{3}\right)_{3}$ sebanyak $0,5 \%$ massa terhadap senyawa prekursor dilarutkan dengan $23 \mathrm{ml}$ metanol lalu dimasukkan ke dalam ultrasonic bath selama 15 menit dalam keadaaan tertutup. Selanjutnya larutan precursor tersebut dimasukkan ke dalam labu tiga leher (Gambar 1a.), dan larutan $\mathrm{NaOH}+\mathrm{Al}\left(\mathrm{NO}_{3}\right)_{3}$ dimasukkan ke dalam buret, dan dilakukan penetesan secara perlahan-lahan kedalam larutan prekursor. Pengadukan terus dilakukan pada suhu $65^{\circ} \mathrm{C}$ selama 150 menit hingga terjadi perubahan warna pada larutan prekursor. Perubahan tersebut, diawali dari larutan keruh berubah menjadi bening (transparan) kemudian berubah kembali menjadi larutan berwarna putih. Larutan putih tersebut kemudian didiamkan selama $48 \mathrm{jam}$, hingga terbentuk endapan putih (gel) dan dilanjutkan ketahap pencucian serta pengeringan (Gambar 1b.).

Pada tahap pencucian, $10 \mathrm{ml}$ hexane dan $10 \mathrm{ml}$ methanol ditambahkan ke dalam endapan gel yang terbentuk kemudian diaduk dengan menggunakan batang pengaduk lalu dipindahkan ke dalam tabung sentrifugasi. Kemudian proses pencucian dibantu dengan perangkat ultrasonic bath dan sentrifugator (kecepatan $4500 \mathrm{rpm}$ ), tahap pencucian pada masing-masing perangkat dilakukan selama 15 
menit. Tahap pencucian fasa gel ini dilakukan sebanyak tiga kali. Dalam tahap ini, diharapkan ion-ion dan sisa-sisa hasil reaksi (berupa senyawa organik) dapat terangkat oleh hexane sehingga hanya tersisa gel $\mathrm{ZnOH}$ yang selanjutnya berubah menjadi $\mathrm{ZnO}$ seiring dengan proses pemanasan berlangsung.

Tahap selanjutnya adalah proses pembuatan serbuk melalui tahap pengeringan. Sampel yang telah dicuci kemudian dikeringkan menggunakan oven vacuum selama 8 jam pada suhu $150^{\circ} \mathrm{C}$. Setelah dikeringkan sampel kemudian digerus secara perlahan menggunakan batang pengaduk sehingga didapatkan serbuk halus $\mathrm{ZnO}$ dan $\mathrm{ZnO}$ :Al. Sampel serbuk kemudian digunakan untuk pengujian struktur kristal, dan SEM. Sedangkan untuk pengujian sifat optik (spektrum fotoluminesensi) serbuk didispersikan terlebih dahulu dengan pelarut metanol,

Pengujian fotokatalis dilakukan dengan menggunakan larutan metil biru sebagai model larutan limbah. Konsentrasi serbuk metil biru tersebut adalah 20mg/L yang dilarutkan dalam aquades. Sebanyak 10mg serbuk katalis didispersikan terlebih dahulu menggunakan aquades sebanyak $20 \mathrm{ml}$. Kemudian untuk membuat larutan uji, masing-masing larutan serbuk katalis ( $\mathrm{ZnO}$ dan $\mathrm{ZnO}$ : $\mathrm{Al}$ ) dicampurkan dengan $10 \mathrm{ml}$ larutan metil biru, lalu diaduk dengan magnetic stirrer selama 10 menit dalam keadaan tertutup. Setelah diaduk, larutan uji kemudian diamati sifat fotokatalitiknya dengan meletakkannya di bawah lampu UV $(368,84 \mathrm{~nm})$ dengan intensitas radiasi sebesar $14 \mu \mathrm{W} / \mathrm{cm}^{2}$ selama 210 menit (Gambar 2). Sampel diambil secara berkala setiap interval waktu 30 menit untuk mengamati perubahan spektrum absorbansi larutan uji.

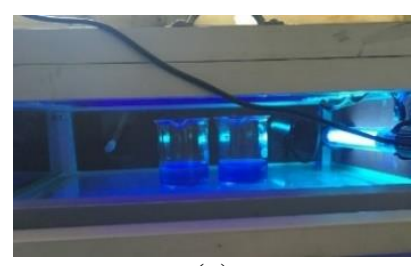

(a)

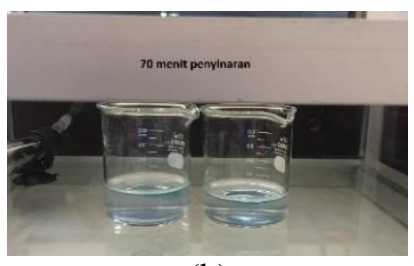

(b)

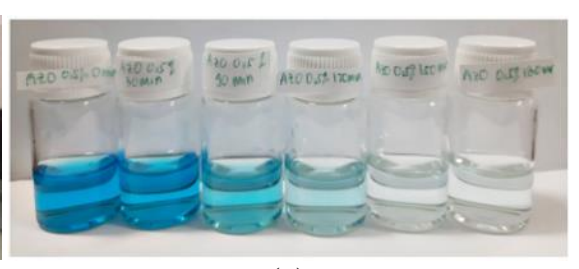

(c)

Gambar 2. (a) Pengujian efek fotokatalitik pada serbuk $\mathrm{ZnO}$ partikel (a). Awal penyinaran dengan lampu UV, (b) Ketika disinari di pertengahan waktu, (c) Perubahan warna pada larutan uji setelah melalui proses penyinaran dari waktu ke waktu

Pengujian berulang serbuk $\mathrm{ZnO}$ :Al sebagai material fotokatalis dilakukan untuk mengetahui sifat fotokorosi dari sampel. Fotokorosi merupakan peristiwa meluruhnya sifat katalitik $\mathrm{ZnO}$ yang disebabkan oleh radiasi UV secara berkepanjangan/terus-menerus. Pada pengujian berulang, setelah kandungan metil biru terdegradasi secara sempurna (larutan telah menjadi bening kembali), larutan MB ditambahkan kembali sehingga konsentrasi MB tetap sama dengan pengujian pertama. Setiap selang waktu 60 menit, larutan diambil untuk dilakukan karakterisasi absorbansi. Kemudian disinari kembali di bawah lampu UV sampai larutan menjadi bening kembali. Tahap ini dilakukan berulang sebanyak 6 kali, yang ditandai dengan perubahan fisik pada serbuk $\mathrm{ZnO}$ :Al dan menghasilkan laju degradasi yang semakin menurun. 


\section{Hasil dan Pembahasan}

Pemindaian menggunakan pencitraan digital SEM untuk sampel serbuk $\mathrm{ZnO}$ dan ZnO:Al dapat dilihat pada Gambar 3 dengan variasi perbesaran 5000x dan 50.000x. Serbuk $\mathrm{ZnO}$ memiliki bentuk/morfologi yang bulat dan cenderung menggumpal. Sedangkan pada sampel serbuk $\mathrm{ZnO}: \mathrm{Al}$, terlihat morfologi yang unik serupa kepingan beserta butiran-butiran yang lebih halus. Kepingan yang terlihat seperti kelopak bunga tersebut kemungkinan berasal dari serbuk nano $\mathrm{ZnO}$ :Al yang menumpuk dan dipengaruhi oleh medan elektrostatis. Sehingga untuk mengetahui morfologi serbuk secara lebih detail dibutuhkan perbesaran yang lebih tinggi.

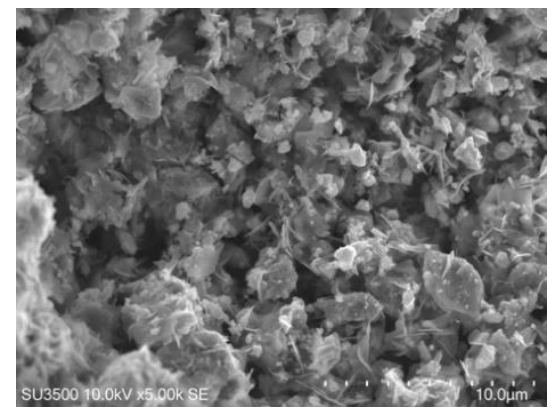

(a)

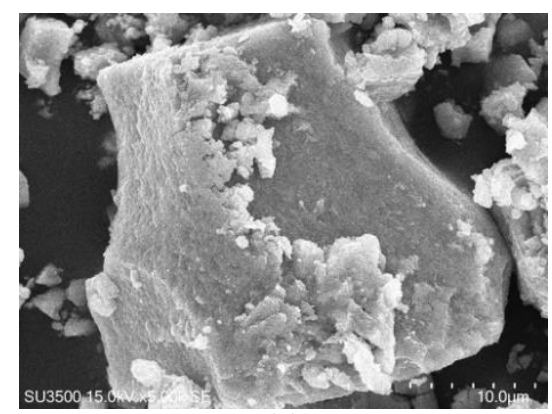

(c)

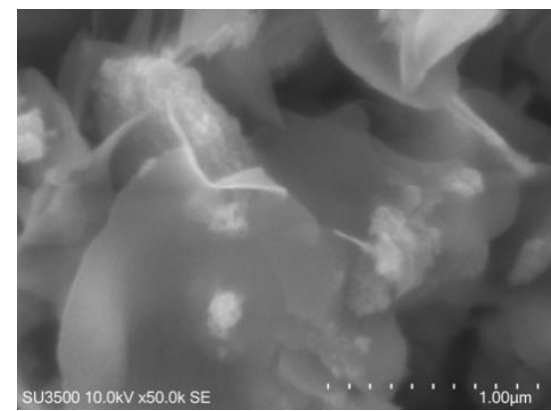

(b)

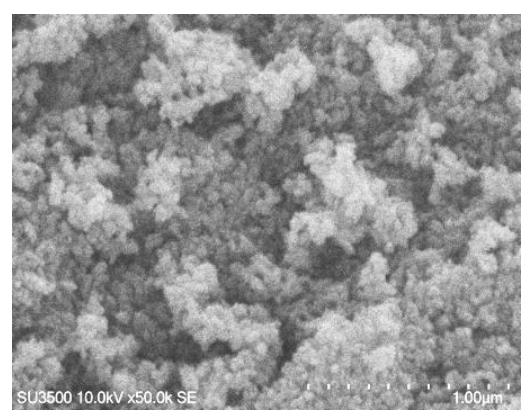

(d)

Gambar 3. Pencitraan SEM serbuk $\mathrm{ZnO}: \mathrm{Al}$ (a-b) dan $\mathrm{ZnO}$ (c-d)

Berdasarkan hasil karakterisasi difraksi sinar-X, diketahui bahwa seluruh sampel $\mathrm{ZnO}$ dan $\mathrm{ZnO}: \mathrm{Al}$ memiliki struktur kristal hexagonal wurtzite. Terlihat pada Gambar 4 masing-masing sampel memiliki posisi puncak difraksi pada sudut yang hampir sama tetapi dengan intensitas yang berbeda. Peningkatan konsentrasi Al menghasilkan pola intensitas yang lebih rendah. Hal ini dapat disebabkan akibat adanya penurunan parameter kisi $a$ dan $c$ [6], sehingga dapat menurunkan distribusi ukuran kristal. Ukuran setiap kristal pada masing-masing orientasi bidang dapat diketahui dengan menggunakan persamaan Debye-Scherrer [7]:

$$
D=\frac{k \lambda}{B \cos \theta_{B}}
$$

$\mathrm{D}$ adalah ukuran (diameter) kristalin, $\lambda$ adalah panjang gelombang sinar-X yang digunakan, $\theta_{B}$ adalah sudut Bragg, B adalah FWHM pada salah satu puncak difraksi sesuai dengan bidang orientasi kristal yang dipilih, dan $\mathrm{k}$ adalah konstanta material $(\mathrm{k} \approx 0,9)$. Hasil perhitungan tersebut diperlihatkan pada Tabel 1 . Ukuran kristal $\mathrm{ZnO}$ dengan orientasi bidang (002) adalah 58,2 nm. Penambahan atom Al 
ternyata mereduksi ukuran kristal pada bidang orientasi ini yaitu menjadi 20,3 nm. Hal tersebut dapat terjadi dikarenakan diameter ion $\mathrm{Al}^{+3}(0,039 \mathrm{~nm})$ lebih kecil daripada $\mathrm{Zn}^{2+}(0,06 \mathrm{~nm})$, sehingga ketika atom $\mathrm{Al}$ menempati lokasi $\mathrm{Zn}$ dalam kisi kristal maka ukuran kristal akan tereduksi [8]. Selain itu, penurunan intensitas difraksi pada sampel dengan penambahan Al sebagai dopan berkaitan pula dengan penurunan ukuran kristal. Reduksi ukuran kristal ini dapat menyebabkan peningkatan luas permukaan partikel $\mathrm{ZnO}$ dan dapat meningkatkan sifat fotokatalitik.

Tabel 1. Ukuran kristal pada serbuk katalis

\begin{tabular}{ccrrr}
\hline Sampel & $(\mathbf{h k l})$ & $\mathbf{2 \theta}\left(^{(}\right)$ & FWHM (20) & D (nm) \\
\hline \multirow{3}{*}{ ZnO } & $(100)$ & 31,8 & 0,8976 & 18,4 \\
& $(002)$ & 34,48 & 0,2856 & 58,2 \\
& $(101)$ & 36,22 & 0,3264 & 51,2 \\
& $(100)$ & 31,57 & 0,2856 & 57,8 \\
ZnO:Al & $(002)$ & 34,22 & 0,816 & 20,3 \\
& $(101)$ & 35,9 & 0,8976 & 18,6 \\
\hline
\end{tabular}

Pengamatan spektrum fotoluminesensi (emisi) dilakukan dengan memberikan radiasi eksitasi dengan panjang gelombang $315 \mathrm{~nm}$ pada setiap sampel. Terdapat penurunan intesitas emisi pada serbuk $\mathrm{ZnO}$ :Al bila dibandingkan dengan sampel serbuk $\mathrm{ZnO}$. Hal ini mengindikasikan bahwa adanya penurunan peristiwa rekombinasi elektron-hole pada sampel $\mathrm{ZnO}$ terdoping $\mathrm{Al}$. Penurunan intensitas emisi tersebut, berkaitan dengan peristiwa pemisahan eksiton yang terjadi secara lebih efisien, sehingga mengasilkan elektron dan hole bebas (muatan bebas). Kedua muatan bebas tersebut, selanjutnya akan bereaksi dengan hidroksil dan oksigen sehingga membentuk hidroksil radikal. Semakin banyak hidroksil radikal yang terbentuk, maka proses degradasi polutan akan semakin cepat. Spektrum emisi pada serbuk ZnO:Al, kemudian didekonvolusi menggunakan persamaan Gaussian sehingga diketahui kemungkinan tingkat-tingkat keadaan energi akibat keberadaan defect.

Berdasarkan spektrum emisi tersebut, terdapat puncak pada daerah UV yang dapat dikaitkan langsung dengan nilai energi gap. Pada dasarnya nilai energi gap yang terbentuk, turut dipengaruhi oleh level energi akibat keberadaan defect state bagi elektron, yaitu berupa $\mathrm{Zn}$ interstisi $\left(\mathrm{Zn}_{\mathrm{i}}\right)$. Jika dianggap spektrum emisi pada daerah UV berkaitan langsung dengan energi gap $\left(E_{g}\right)$, maka nilai $E_{g}$ untuk masing-masing sampel adalah 3,27 eV untuk serbuk $\mathrm{ZnO}$ dan 3,2 eV untuk serbuk $\mathrm{ZnO}$ :Al. Selain itu, dapat diketahui tingkatan energi yang berkaitan dengan cacat pada kedua sampel, seperti yang diperlihatkan pada Gambar 5 (b dan c). Berdasarkan hasil pengamatan, serbuk nano $\mathrm{ZnO}$ memiliki cacat oxygen interstitial pada tingkat energi 2,36 eV (517,36 $\mathrm{nm})$ dan $\mathrm{Zn}$ vakansi pada tingkat energi 2,98 eV (414,84 $\mathrm{nm}$ ), sedangkan serbuk ZnO:Al kemungkinan besar didominasi oleh cacat $\mathrm{Zn}$ interstisi dengan tingkat energi pada $2,79 \mathrm{eV}(443,2 \mathrm{~nm})$ dan oksigen vakansi pada 2,49 eV (497,3 nm) [9]. 


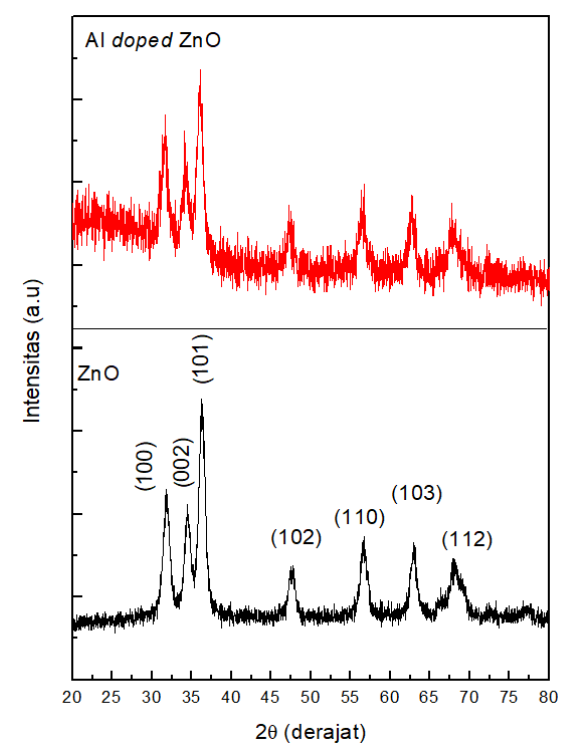

Gambar 4. Spektrum difraksi sinar-X. Kedua sampel memiliki struktur kristal yang sama yaitu heksagonal wurtzite dan sesuai dengan spektrum difraksi standar bagi ZnO (JCPDS no.361451)

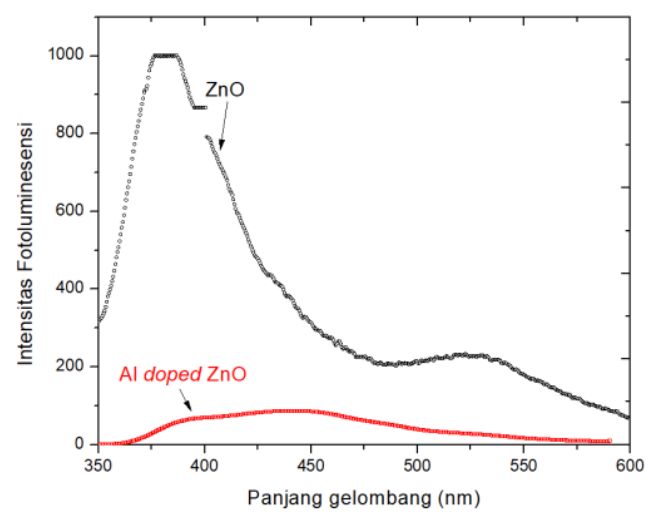

(a)

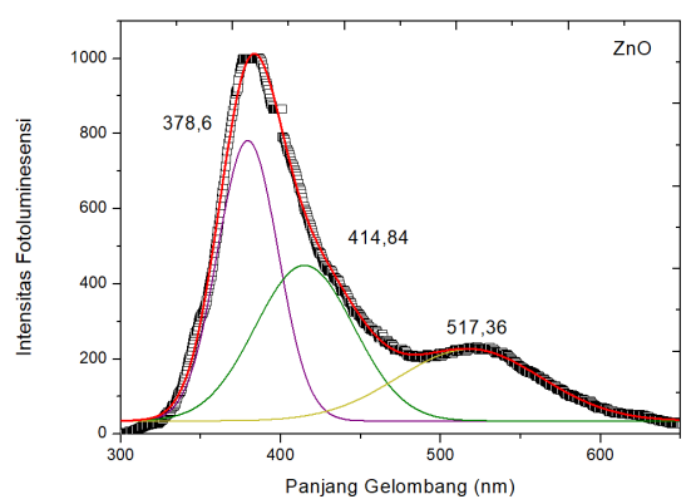

(b)

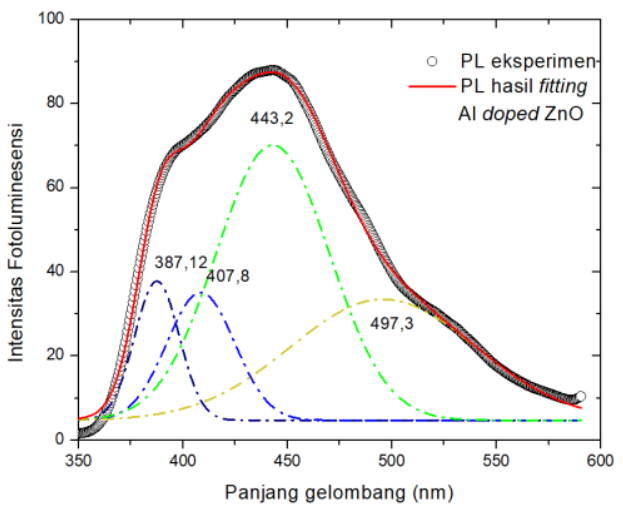

(c)

Gambar 5. Spektrum emisi pada kedua sampel serbuk $\mathrm{ZnO}$ dan $\mathrm{ZnO}$ : $\mathrm{Al}$ yang terdispersi di dalam metanol. Hasil dekonvolosi (fitting) menggunakan distribusi Gaussian, untuk (b) $\mathrm{ZnO}$ dan (c) $\mathrm{ZnO}: \mathrm{Al}$ 
Pengujian fotokatalis yang dilakukan menggunakan metil biru sebagai model larutan limbah. Gambar 6 menunjukkan spektrum absorbansi pada larutan uji selama penyinaran untuk setiap penggunaan sampel $\mathrm{ZnO}$ dan $\mathrm{ZnO}$ :Al sebagai katalis. Terlihat bahwa penambahan Al sebagai kationik dopan mampu meningkatkan aktivitas fotokatalis. Inset pada Gambar 6 menunjukkan laju fotodegradasi pada metil biru dengan menggunakan persamaan konstanta laju reaksi Pseudo [10],

$$
-\ln \left(\frac{A}{A_{0}}\right)_{\lambda=664,5 \mathrm{~nm}}=k t
$$

A dan $A_{0}$ adalah nilai absorbansi pada panjang gelombang 664,5 nm, $k$ adalah laju fotodegradasi dan $t$ adalah waktu penyinaran. Dengan menggunakan Persamaan 2, diketahui bahwa pada penggunaan sampel katalis $\mathrm{ZnO}$ :Al, laju fotodegradasi yang dihasilkan ternyata lebih cepat yaitu $0,02185 /$ menit. Sedangkan pada sampel $\mathrm{ZnO}$ didapatkan laju fotodegradasi sebesar 0,0107/menit.

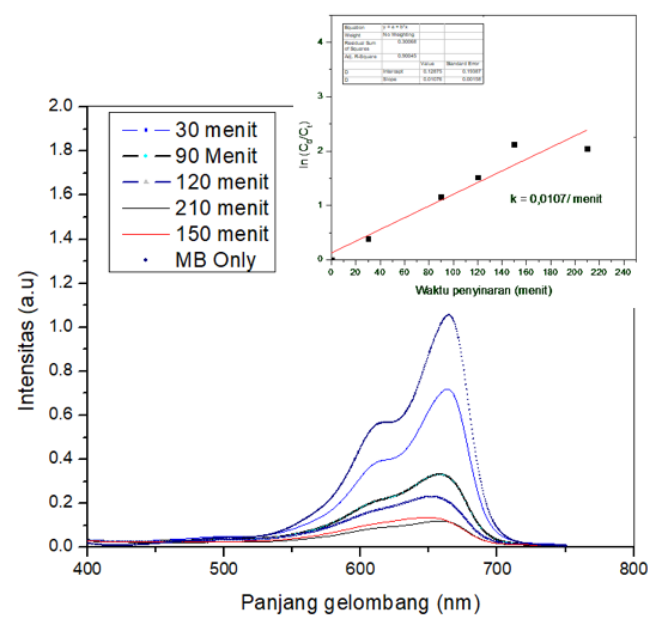

(a)

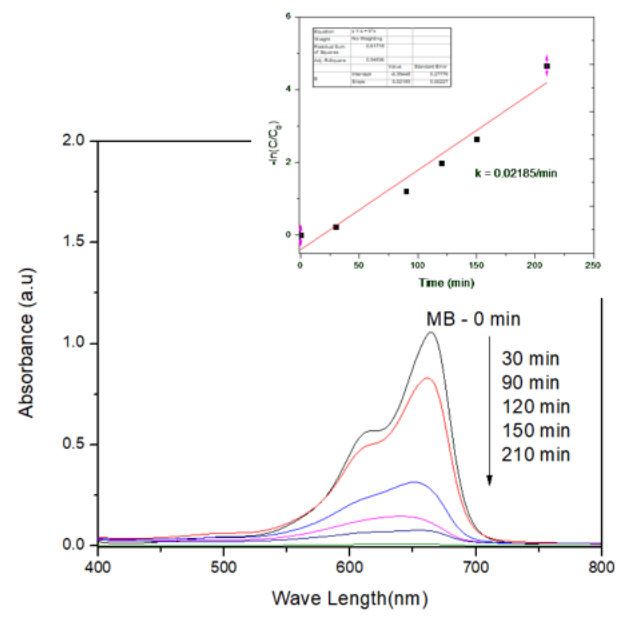

(b)

Gambar 6. Spektrum absorbansi pada larutan uji setiap interval waktu (30 - 60 menit). (a) $\mathrm{ZnO}$ dan (b) $\mathrm{ZnO}: \mathrm{Al}$

Dikaitkan dengan struktur dan ukuran kristal yang terbentuk, maka peningkatan aktivitas fotokatalitik pada sampel $\mathrm{ZnO}$ :Al dapat diasumsikan dengan menurunnya ukuran kristal pada bidang 002. Bidang (002)-Zn diketahui memiliki polaritas yang besar dan mudah menarik hidroksil ( $\mathrm{OH}-)$. Gugus $\mathrm{OH}$ kemudian bereaksi dengan $\mathrm{h}+$ yang selanjutnya membentuk $\mathrm{OH}$ ( $\mathrm{OH}$ radikal) [11]. Sehingga, dengan meningkatnya luas permukaan aktif pada material katalis, maka daerah pertemuan antara partikel katalis dengan polutan akan turut meningkat, dan menyebabkan proses penguraian polutan (MB) menjadi lebih efisien dan efektif.

Jika dikaitkan dengan tingkat kecacatan atau defect states dari setiap sampel (berdasarkan pada spektrum emisi masing-masing sampel), maka diketahui bahwa keberadaan oksigen vakansi yang dimiliki oleh $\mathrm{ZnO}$ : Al dapat meningkatkan aktivitas fotokatalitik. Hal tersebut berkaitan dengan kekosongan oksigen pada sampel, akan menyebabkan muatan bebas positif (hole) lebih cepat menarik oksigen dan membentuk $\mathrm{H}_{2} \mathrm{O}_{2}$ yang selanjutnya akan memproduksi hidroksil radikal. 
Skema reaksi fotokatalitik secara umum dapat dilihat pada beberapa persamaan reaksi (3) s.d (10) [12],

$$
\begin{aligned}
& \mathrm{ZnO}\left(\mathrm{h}_{(\mathrm{VB})}^{+}\right)+\mathrm{OH}^{-} \rightarrow \mathrm{ZnO}+\mathrm{OH} \cdot \\
& \mathrm{ZnO}\left(\mathrm{e}_{(\mathrm{CB})}^{-}\right)+\mathrm{O}_{2} \rightarrow \mathrm{ZnO}+\mathrm{O}_{2} \cdot- \\
& \mathrm{O}_{2} \cdot{ }^{-}+\mathrm{H}^{+} \rightarrow \mathrm{HO}_{2} \cdot \\
& \mathrm{HO}_{2} \cdot+\mathrm{HO}_{2} \cdot \rightarrow \mathrm{H}_{2} \mathrm{O}_{2}+\mathrm{O}_{2} \\
& \mathrm{ZnO}\left(\mathrm{e}_{(\mathrm{CB})}^{-}\right)+\mathrm{H}_{2} \mathrm{O}_{2} \rightarrow \mathrm{OH}^{\circ}+\mathrm{OH}^{-} \\
& \mathrm{H}_{2} \mathrm{O}_{2}+\mathrm{O}_{2} \cdot \rightarrow \mathrm{OH} \cdot+\mathrm{OH}^{-}+\mathrm{O}_{2} \\
& \mathrm{H}_{2} \mathrm{O}_{2}+\mathrm{hv} \rightarrow 2 \mathrm{OH} \cdot
\end{aligned}
$$

Selain itu, kehadiran ionik $\mathrm{Al}^{3+}$ pada sampel terdoping akan menginduksi lebih banyak $\mathrm{O}_{2}$ pada permukaan $\mathrm{ZnO}$ sehingga $\mathrm{O}_{2}$ akan bertindak sebagai electron scavener yang menghambat terjadinya rekombinasi elektron dan membentuk radikal superoksida. Kontradiktif dengan defect state akibat kehadiran oksigen intertisi, yang mana ternyata dapat mengurangi aktivitas fotokatalis karena reaksi antara hole dan oksigen aktif pada permukaan $\mathrm{ZnO}$, dapat menyebabkan hole terperangkap sehingga tidak dapat bereaksi dengan ion hidroksil untuk melarutkan polutan.

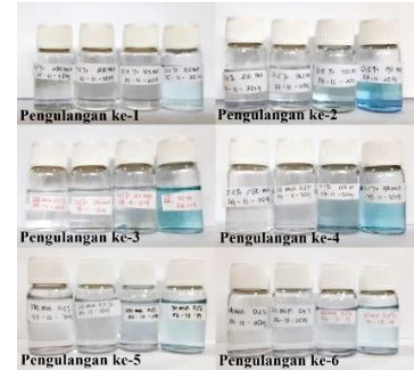

(a)

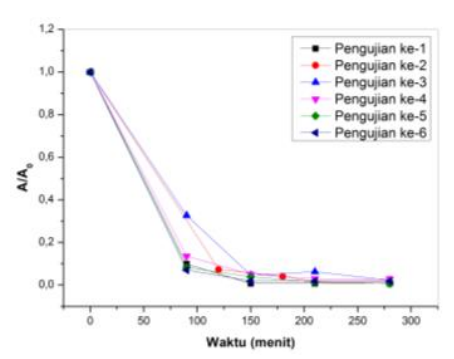

(b)

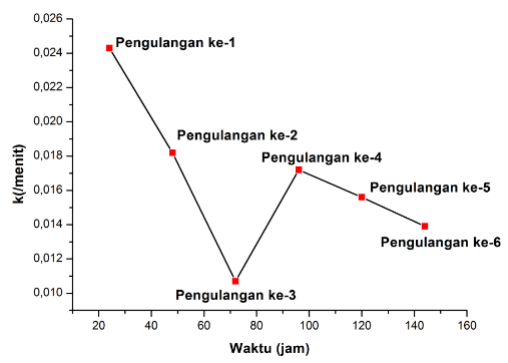

(c)

Gambar 7. (a) Foto prubahan warna pada larutan uji setiap pengulangan. (b) Perubahan perbandingan absorbansi larutan uji terhadap waktu. (d) Laju reduksi penguraian MB pada larutan uji pada pemakaian berulang

Pengujian fotokatalis berulang dilakukan untuk mengetahui sifat korosi pada sampel khususnya serbuk ZnO:Al. Untuk pengujian berulang ini, larutan yang telah jernih ditambahkan kembali larutan metil biru sehingga didapatkan larutan dengan konsentrasi metil biru yang sama disetiap siklus pengujian. Prosedur pengujian sifat fotokatalitik sama dengan pengujian sebelumnya. Pada penelitian ini pengujian fotokatalis dilakukan sebanyak enam kali dengan kondisi masih mampu menjernihkan air (Gambar 7a). Proses pengujian fotokorosi dihentikan, ketika serbuk $\mathrm{ZnO}$ telah mengalami perubahan warna. 
Perubahan warna yang terjadi, pada dasarnya mengindikasikan terdapat pengurangan kinerja katalis dalam memecah metil biru dan adanya penambahan peran baru bagi $\mathrm{ZnO}$ :Al, yaitu sebagai material nano-adsorben. Perubahan puncak absorbansi untuk uji fotokatalis berulang diperlihatkan pada Gambar 7b. Gambar 7c, merupakan perubahan laju kinetik serbuk katalis dalam mendegradasi MB di dalam larutan uji. Terlihat bahwa terjadi penurunan laju reduksi sejak pemakaian kedua, dan ketiga. Hal diluar dugaan terjadi, yaitu adanya peningkatan laju degradasi pada siklus ke-4. Hal ini kemungkinan terjadi akibat senyawa metil biru tidak hanya terurai tetapi turut tertempel (mengalami kemisorpsi) dengan $\mathrm{ZnO}: \mathrm{Al}$, sehingga proses penjernihan larutan uji berlangsung lebih cepat.

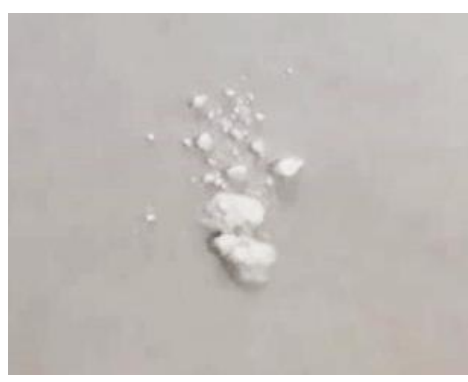

(a)

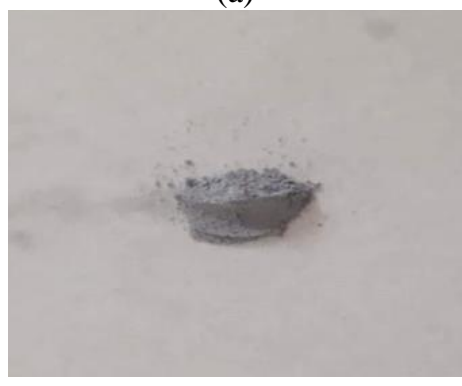

(c)

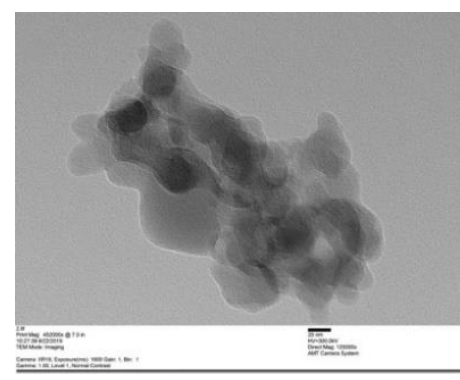

(b)

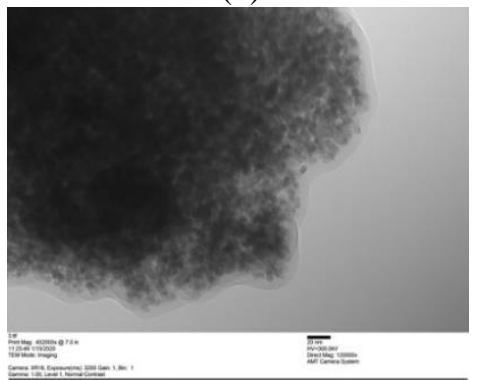

(d)

Gambar 8. (a) dan (b) Serbuk $\mathrm{ZnO}$ : Al sebelum digunakan beserta hasil pencitraan dengan TEM. (c) dan (d) Serbuk ZnO:Al setelah pengujian berulang 6 siklus beserta hasil pemindaian TEM

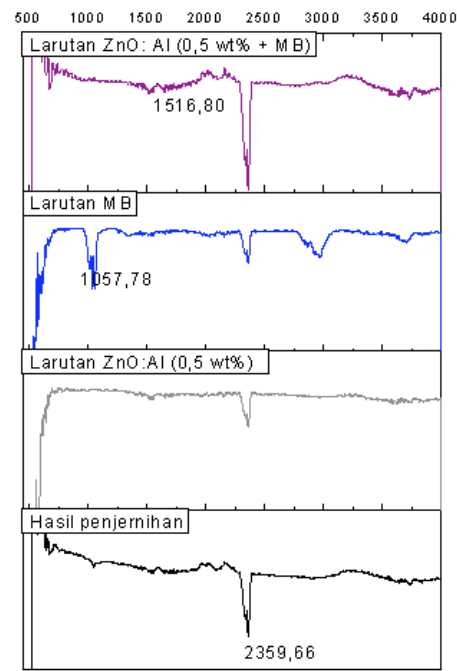

Bilangan $G$ elombang $\left(\mathrm{cm}^{-1}\right)$

Gambar 9. Hasil karakterisasi FTIR dalam fasa larutan 
Hal tersebut juga mengindikasikan bahwa kinerja serbuk $\mathrm{ZnO}$ :Al yang berperan untuk memecah senyawa metil biru mengalami penurunan sehingga memunculkan sifat atau karakteristik sebagai material nano-adsorben. Pada siklus kelima, laju degrasi metil biru kembali menurun, dan serbuk katalis mulai mengalami perubahan warna yang terlihat pada Gambar 8c. Selain itu, proses fotokorosi atau fotodissolusi dari katalis $\mathrm{ZnO}: \mathrm{Al}$ kemungkinan turut terjadi mulai siklus ke 5. Hal ini dapat teramati dari adanya perubahan morfologi $\mathrm{ZnO}$ berdasarkan hasil TEM dari sebelum digunakan dan sesudah digunakan pada pemakaian berulang (Gambar 8b dan 8d).

Untuk mengetahui secara pasti penguraian senyawa metil biru (MB), dilakukan karakterisasi FTIR pada empat sampel dalam fasa larutan. Sampel pertama merupakan larutan uji setelah penjernihan fotokatalis (siklus 6-hasil penjernihan) dengan kondisi larutan yang jernih, sampel kedua merupakan serbuk katalis $\mathrm{ZnO}: \mathrm{Al}$ yang terdispersi dalam air, sampel ketiga merupakan larutan metil biru (MB) dan sampel keempat merupakan campuran larutan $\mathrm{ZnO}: \mathrm{Al}$ (Al doped $\mathrm{ZnO}$ 0,5 wt\% + metil biru) yang telah diuji fotokatalisnya sebanyak 6 kali. Gambar 9 menunjukkan bahwa serbuk $\mathrm{ZnO}$ tetap mampu mendegradasi metil biru walau telah mengalami fotokorosi/fotodisolusi. Serapan yang terlihat pada larutan MB tidak terlihat lagi baik pada sampel hasil penjernihan atau pada larutan $\mathrm{ZnO}: \mathrm{Al}+\mathrm{MB}$, khususnya pada bilangan gelombang $1057,78 \mathrm{~cm}^{-1}$. Terjadinya peristiwa fotokorosi atai fotodisolusi, diperkirakan terjadi karena adanya perubahan morofologi pada serbuk katalis, seperti yang teramati dari hasil pemindaian TEM (Gambar 9b dan 9d) dan tidak teramatinya gugus serapan bagi ikatan $\mathrm{Zn}-\mathrm{O}$ pada $445 \mathrm{~cm}^{-1}$ pada sampel larutan $\mathrm{ZnO}: \mathrm{Al}+\mathrm{MB}$. Fotodissolusi dapat terjadi akibat penyerapan foton secara terus menerus pada material katalis sehingga menyebabkan $\mathrm{ZnO}$ terurai menjadi ion $\mathrm{Zn}^{2+}$ dan oksigen yang terlarut di air, seperti pada reaksi kimia persamaan (11) [13].

$$
\mathrm{ZnO}+2 h^{+} \rightarrow \mathrm{Zn}^{2+}+\frac{1}{2} \mathrm{O}_{2}
$$

\section{Kesimpulan}

Penambahan Al sebanyak 0,5\% massa sebagai kationik dopan pada $\mathrm{ZnO}$ dapat meningkatkan aktivitas fotokatalitik, dibandingkan dengan $\mathrm{ZnO}$ tanpa dopan. Dopan Al dapat menyebabkan ukuran kristal menjadi lebih kecil, khususnya pada bidang orientasi (002). Peningkatan aktivitas fotokatalis pada sampel $\mathrm{ZnO}: \mathrm{Al}$ tersebut dapat dikaitkan berkurangnya ukuran kristal ataupun distribusi partikel. Reduksi ukuran tersebut tentu saja dapat meningkatkan luas permukaan katalis khususnya pada kristal dengan bidang (002), sehingga meningkatkan aktivitas fotokatalis. Selain itu, dikaitkan dengan sifat emisi dari kedua sampel, diketahui bahwa keberadaan dopan $\mathrm{Al}$ dapat meningkatkan defect $\mathrm{V}_{\mathrm{o}}$ (vakansi oksigen) dan mengurangi/meniadakan defect $\mathrm{O}_{i}$, yang diketahui dapat meningkatkan aktivitas katalis. Pada pengujian berulang dari serbuk $\mathrm{ZnO}$ :Al, diketahui bahwa material tersebut masih mampu menghilangkan senyawa MB, walaupun diperkirakan peristiwa yang terjadi tidak murni reaksi fotokatalitik, tetapi terjadi pula peristiwa penyerapan partikel $\mathrm{MB}$ pada permukaan $\mathrm{ZnO}$ :Al. Hal tersebut ditandai dengan terjadinya perubahan warna pada serbuk katalis. Selain itu, turut diperkirakan bahwa peristiwa penyerapan senyawa $\mathrm{MB}$ beriringan dengan proses foto-dissolusi serbuk $\mathrm{ZnO}$ menjadi ion $\mathrm{Zn}^{2+}$, dan $\mathrm{O}_{2}$ di dalam larutan 


\section{Ucapan Terima Kasih}

Penulis mengucapkan terimakasih kepada Dekan FMIPA beserta jajarannya, dan DRPMI Universitas Padjadjaran. Penelitian ini dilaksanakan dengan menggunakan hibah dana penelitian nasional dengan skema Penelitian Dasar Unggulan Perguruan Tinggi (PDUPT), tahun anggaran 2019 berdasarkan kontrak penelitian nomor 2783/ UN6.D/LT/2019.

\section{DaftarPustaka}

1. B. Sunandan, K.P. Samir dan D. Joydeep. Nanostructured Zinc Oxide for Water Treatment, Nanoscience \& Nanotechonology-Asia, 2012, 2.

2. Li, J. Fei dan Junbai. 2009. Metal Oxide Nanomaterials for Water Treatment. Weinheim: Nanomaterials for the Life Science.

3. M. Anjum, R. Miandad, M. Waqas, F.Gehany. Remediation of Wastewater Using Various Nanomaterials, Arabian Journal of Chemistry (2016).

4. A.R. Hakim dan A. Haris. Sintesis Fotokatalis ZnO-Al dan Aplikasinya pada Degradasi Fenol dan Reduksi Cd(II) secara Simultan. Jurnal Kimia Sains dan Aplikasi (2016) 30.

5. D. P. hanavi, C. G. Afrilia, L. Safriani, A. Aprilia, Sintesis ZnO serbuk dan penggunaannya sebagai fotoanoda pada sel surya tersensitasi warna. Jurnal Material dan Energi, Vol 9 No. 1 (2019) 44.

6. M.Ahmad, E.Ahmed, Y.Zhang, N.R. Khalid, J. Xu, M. Ullah. Preparation of Highly Efficient Al -doped ZnO Photocatalyst by Combustion Synthesis, Current Applied Physic 3.

7. A. Aprilia, A. Bahtiar, L. Safriani, Ayunita C C, Afifah N, N Syakir, Risdiana, T Saragi, S Hidayat, Fitrilawati and R E Siregar. Time of Growth Dependent of $\mathrm{ZnO}$-Nanorods by Self Assembly Methods and its Structural Properties. IOP Conf. Series: Materials Science and Engineering 196 (2017) 012046.

8. F. Ajala, A. Hamrouni, A. Houas, H. Lachheb, B. Megna, L. Palmisano, F. Parrino. The Influence of Al Doping on The Photocatalytic Activity of Nanostuctured ZnO: The Role of Adsorbed Water 445 (2018) 376-384.

9. S. Vempati, J. Mitra, and P. Dawson. One step synthesis of ZnO nanosheets: a blue white fluophore. Nanoscale Research Letter, 7:470 (2012).

10. F.Bensouici, M.Bououdina, A.A. Dakhel, T.Souier, R.Tala-Ighil, M.Toubane, A.Iratni, S.Liu, W.Cai. Al Doping Effect on the Morphology, Structural and Photocatalytic Properties of $\mathrm{TiO}_{2}$ Thin Layer. Thin Solid Film 616 (2016) 655661.

11. M. W. Allen, D. Y. Zemlyanov, G.I.N. Waterhouse, J.B. Metson, T.D. Veal, C. F. McConville, and S. M. Durbin. Polarity effects in x-ray photoemission of $\mathrm{ZnO}$ and other wurtzite semiconductors. Applied Phytsics Letter 98, (2011) 101906.

12. C. B. Ong, L. Y. Ng, and A. W. Mohammad. 2018. A Review of ZnO Nanoparticles as Solar Photocatalysts: Synthesis, Mechanism and Application. Renewable and Sustainable Energy Reviews. Vol 81: 536-551.

13. C. M. Taylor, Anyela Ramirez-Canon, J. Wenk and D. Mattia. Enhancing the photo-corrosion resistance of $\mathrm{ZnO}$ nanowire photocatalyst. Journal of Hazardous Materials 378 (2019) 120799. 